\title{
Deep-water clastic systems in the upper carboniferous (upper mississippian-lower pennsylvanian) shannon basin, western Ireland \\ DOI:
}

10.1306/021417DIG17099

\section{Document Version}

Accepted author manuscript

Link to publication record in Manchester Research Explorer

Citation for published version (APA):

Martinsen, O. J., Pulham, A. J., Elliott, T., Haughton, P., Pierce, C., Lacchia, A. R., Barker, S., Latre, A. O., Kane, I., Shannon, P., \& Sevastopulo, G. D. (2017). Deep-water clastic systems in the upper carboniferous (upper mississippian-lower pennsylvanian) shannon basin, western Ireland. AAPG Bulletin, 101(4), 433-439.

https://doi.org/10.1306/021417DIG17099

\section{Published in:}

AAPG Bulletin

\section{Citing this paper}

Please note that where the full-text provided on Manchester Research Explorer is the Author Accepted Manuscript or Proof version this may differ from the final Published version. If citing, it is advised that you check and use the publisher's definitive version.

\section{General rights}

Copyright and moral rights for the publications made accessible in the Research Explorer are retained by the authors and/or other copyright owners and it is a condition of accessing publications that users recognise and abide by the legal requirements associated with these rights.

\section{Takedown policy}

If you believe that this document breaches copyright please refer to the University of Manchester's Takedown Procedures [http://man.ac.uk/04Y6Bo] or contact uml.scholarlycommunications@manchester.ac.uk providing relevant details, so we can investigate your claim.

\section{OPEN ACCESS}




\section{Deep-Water Clastic Systems in the Upper Carboniferous (Upper Mississippian - Lower Pennsylvanian) Shannon Basin, western Ireland}

Authors: Ole J. Martinsen ${ }^{1}$, Andrew J. Pulham ${ }^{2}$, Trevor Elliott ${ }^{3}$, Peter Haughton ${ }^{4}$, Colm Pierce ${ }^{4,5}$, Anthea R. Lacchia ${ }^{4}$, Simon Barker ${ }^{1}$, Arnau Obradors Latre ${ }^{4}$, Ian Kane ${ }^{1}$, Patrick Shannon $^{4}$, George D. Sevastopulo ${ }^{6}$

1: Statoil, PO Box 7200, 5020 Bergen, Norway

2: ESACT, Boulder, Colorado, USA

3: Deceased

4: University College, Dublin, Ireland

5: Current address: Aberdeen University, Aberdeen, UK

6: Trinity College, Dublin, Ireland

\section{ABSTRACT}

The Upper Carboniferous Shannon Basin of western Ireland contains a more than 2300 m thick basin-fill succession, shallowing upwards from deep-water to deltaic and incised fluvial deposits. The deep-water basin floor and slope succession is world-renowned as an analogue for hydrocarbon-bearing deep-water sandstones on several continental margins such as the basins in East and West Africa, South America and the Gulf of Mexico, and not least offshore northwest Europe.

The Shannon Basin is frequently visited by both academia and industry for research and training purposes. A series of behind- outcrop research boreholes reveals the subsurface expression of the deep-water rocks and is complemented by seismic scale cliff exposures. The succession is interpreted as a first-order basin-scale linked sedimentary system. This system can be analyzed using the principles of source-to-sink analysis and leaves the visitor with a complete picture of the basin fill, enhanced by spectacular sedimentological and stratigraphic detail.

\section{Petroleum geological significance of the Shannon Basin}

Since the early 1950s, geologists from academia and industry have visited the Upper Carboniferous (Upper Mississippian - Lower Pennsylvanian) Shannon Basin of western Ireland for research and training purposes (Figs. 1 and 2; e.g. Hodson, 1954; Gill and Kuenen, 1958; Hodson and Lewarne, 1961; Rider, 1974, Martinsen, 1989, Pulham, 1989; Elliott and Pulham, 1990, Collinson et al., 1991; Chapin et al., 1994; Davies and Elliott, 1996; Elliott, 2000;

Martinsen et al., 2000, 2003; Sullivan et al., 2000; Martinsen and Collinson, 2002; Lien et al., 2003; Wignall and Best, 2000, 2004; Strachan and Allsop, 2006; Pyles, 2008; Pyles et al., 2014; Lacchia, 2016). It is one of the most used outcrop localities globally for petroleum geological 
training (cf. also AAPG Explorer, 2012). The Shannon Basin (Fig. 1) offers a unique, complete continental margin-scale perspective of a clastic basin-fill succession (Fig. 2). It includes examples of a petroleum source rock, deep-water to shallow-water to fluvial reservoir rock types and structural traps, and allows for in-depth discussions and comparisons to petroleum systems and plays in active, offshore exploration areas globally.

\section{Tectonics, eustasy and stratigraphy}

A series of intracratonic basins developed between Laurentia and Gondwana in northwestern Europe in latest Devonian and Dinantian time (Leeder and McMahon, 1988). The Shannon Basin is elongate about an ENE-WSW line passing through the present Shannon Estuary, a line generally accepted to be the lapetus Suture (Freeman et al., 1988). McKerrow and Soper (1989) showed from BIRPS deep seismic data offshore Ireland that several deep structures dip to the north and come close to surface near the Shannon Estuary. These structures are interpreted as original Caledonian thrusts which were reactivated as major extensional faults during Devonian and Dinantian extension. The trough-shaped Shannon Basin may compare with a major halfgraben and fault-related subsidence may be inferred from pronounced thickness variations in the lower basin fill (Collinson et al., 1991). The basin was deformed and inverted during the mid- to late Stephanian (Late Pennsylvanian) by Variscan deformation. The Shannon Basin has an unusual thermal history with vitrinite reflectance values of 6.5-7.0\%; (Goodhue and Clayton, 1999). This is attributed to the expulsion of hot fluids from the Munster Basin to the south as it was being deformed shortly after accumulation of the Shannon Basin fill succession (Fitzgerald et al., 1994).

Sea level fluctuations in the Late Carboniferous were dominated by a glacial-eustatic component related to the Gondwanan ice sheet and attained scales and periodicities comparable to Pleistocene glaciations (Rygel et al., 2008). Condensed sections linked to maximum flooding formed during glacio-eustatic high sea level with distinctive ammonoid bands (Holdsworth and Collinson, 1988). Regionally widespread sequence boundaries formed during falling sea level and formed incised valleys (Hampson et al., 1997). Climatically, northern Europe was equatorial during the Late Carboniferous.

The more than $2300 \mathrm{~m}$ thick basin-fill succession (Fig. 2) contains a shallowing-upward succession starting from deep-water shales and siltstones (Clare Shales; 275 m), through a sand-rich deep-water fan complex (Ross Formation, $\sim 495 \mathrm{~m}$ ), overlain by a deep-water slope succession (Gull Island Formation, $\sim 550 \mathrm{~m}$ ), which in turn contains a gradational passage into a deep-water fronted deltaic succession (Tullig Cyclothem, $\sim 210 \mathrm{~m}$ ). A further four deltaic cyclothems (Kilkee, Doonlicky, Cyclothems IV and V; 800 m) cap the basin-fill succession (Fig. 
2). The basin-fill succession formed by progradation of a $1^{\text {st }}$ order clastic margin punctuated by several higher-order cycles of sediment input and abandonment.

The basin-fill succession compares with hydrocarbon-bearing continental margin and intracratonic successions globally in terms of large scale stratigraphy and reservoir architecture (Chapin et al., 1994; Martinsen et al., 2000, Sullivan et al., 2000; Pyles 2008). Field logistics and proximity as well as safety and security are well-established. The succession is also coeval to active petroleum systems in northern England as well as in the North Sea, with time-correlative formations to the Clare Shales providing the source rock. Lately, questions and expectations have arisen as to whether the Clare Shales in itself is an unconventional shale gas petroleum system with an independent energy company, Enegi Oil, taking a 100\% working interest in County Clare (HartEnergy, 2011).

\section{The Shannon Basin borehole project}

A consortium consisting of Statoil and University College Dublin (UCD) drilled 12 behindoutcrop wells targeting the sand-rich Ross Formation. These wells penetrate up to $300 \mathrm{~m}$ of Ross Sandstone stratigraphy, target various intervals and collectively create a coherent and robust stratigraphic framework for the Ross Sandstone together with extensive former and recent field studies (Pierce et al., 2010; Lacchia, 2016; Pierce, 2016). Furthermore, they include a complete suite of core and well log data, bridging with and much more clearly showing the subsurface application of the extensive outcrop data than was possible previously.

\section{Source-to-sink analysis of the Shannon Basin fill}

An additional asset of the Shannon Basin outcrop succession is that it lends itself to source-tosink analysis (S2S; Sømme et al., 2009). At outcrop, this approach has not been used extensively, as it requires reconstruction of one of the S2S segments from the outcrop data. In well-preserved, linked and complete basin-fill successions like the Shannon Basin fill, this is possible (Martinsen, 2015).

The Gull Island Formation measures $700 \mathrm{~m}$ in vertical thickness (Fig 2). Using a compaction factor of $30 \%$ for the silt-dominated section, leaves an decompacted vertical thickness of the slope succession of $1000 \mathrm{~m}$. Using a sine function for a slope angle of $1-2^{\circ}$, leaves a slope length of respectively 28.6 and $57.3 \mathrm{~km}$. Input of those values to the global S2S statistics of Sømme et al (2009), provides dimensions for other key elements of the Shannon Basin S2S system Comparing this system and the profile to other sand prone submarine fan S2S settings (Martinsen 2015), implies a narrow shelf width and a catchment with the ability to store and capture larger volumes of sediment than for example, the California Borderland systems (Covault et al., 2011). The interpreted narrow shelf implies elevated potential for sand supply to 
the deep-water areas, particularly during sea-level lowstand and this can explain the sand-rich nature of the Ross submarine fan complex. The analysis suggests a Ross Fan length of 150-200 $\mathrm{km}$ and area of around $10000 \mathrm{~km}^{2}$. An important modifying element is the interpretation that the Ross submarine fan complex was deposited within the confines of the Shannon basinal trough, aligned parallel to the Shannon Estuary above the lapetus Suture (see above). The effect of this relative to deposition on an unconfined basin plain would be to narrow the width of the fan and extend the length, provided sediment volumes were constant.

In conclusion, the ability to perform an outcrop-based S2S analysis of the Shannon Basin fill adds to the exploration value of visiting these field localities. Although the output values for the basin fill system are guiding figures and must honor and be calibrated to local mapping, they provide important scaling relationships to understand the magnitude of the original depositional system. 


\section{REFERENCES}

AAPG Explorer, 03/2012, Ireland Outcrops Still Yield Deep Secrets, http://www.aapg.org/publications/news/explorer/2012/03mar/articleid/3181/march-2012.

AAPG Explorer, 03/2012, Clare Research Has Far-Reaching Impact, http://www.aapg.org/publications/news/explorer/2012/03mar/articleid/3181/march-2012.

Chapin, M.A., P. Davies, J.L. Gibson and H.S. Pettingill, H.S., 1994, Reservoir architecture of turbidite sheet sandstones in laterally extensive outcrops, Ross Formation, western Ireland: 15th Annual GCSSEPM Research Conference, p. 53-68.

Collinson J.D., O.J. Martinsen, B. Bakken and A. Kloster, 1991, Early fill of the Western Irish Namurian basin: a complex relationship between turbidites and deltas: Basin Research, v. 3, p. 223-242.

Covault, J.A., B.W. Romans, S.A. Graham, A. Fildani and G.E. Hilley, 2011, Terrestrial source to deep-sea sink sediment budgets at high and low sea levels: Insights from tectonically active Southern California: Geology, v. 39, p. 619-622.

Davies, S.J. and T. Elliott, 1996, Spectral gamma ray characterization of high resolution sequence stratigraphy: examples from Upper Carboniferous fluvio-deltaic systems, Co. Clare, Ireland, in, J.A. Howell and J.F. Aitken, eds., High-Resolution Sequence Stratigraphy-Innovations and Applications: Geological Society of London Special Publication, v. 104, p.25-35.

Elliott, T., 2000, Depositional architecture of a sand-rich, channelized turbidite system: the upper Carboniferous Ross Sandstone Formation, Western Ireland: in Deep-Water Reservoirs of the World, GCSSEPM Foundation 20th Annual Research Conference, Houston, Texas, December 3-6, 2000, p.342-373.

Fitzgerald, E., M. Feely, J. D. Johnston, G. Clayton, L. J. Fitzgerald and G. D. Sevastopulo, 1994, The thermal history of west Clare, Ireland: Geological Magazine, v. 131, p. 545-558.

Freeman, B., S.L. Klemperer and R.W. Hobbs, 1988, The deep structure of northern England and the lapetus Suture Zone from BIRPS deep seismic reflection profiles: Journal of the Geological Society of London, v. 145, p. 727-774.

Gill, W. D., and P. Kuenen, 1958, Sand volcanoes on slumps in the Carboniferous of County Clare, Ireland: Quarterly Journal of the Geological Society, v. 113, p. 441-460.

HartEnergy, 2011, Luck of the Irish Shales, http://www.ugcenter.com/luck-irish-shales-590676. 
Hodson, F., 1954, The beds above the Carboniferous Limestone in County Clare, Ireland: Journal of the Geological Society, v. 109, p.259-283.

Hodson, F. and G.C. Lewarne, G.C., 1961, A mid-Carboniferous (Namurian) basin in parts of the Counties of Limerick and Clare, Ireland: Journal of the Geological Society of London, v. 117, p.303-333.

Holdsworth, B.K. and J.D. Collinson, 1988, Millstone Grit cyclicity revisited, in, B.M. Besly and G.K. Kelling, eds., Sedimentation in a Synorogenic Basin Complex: the Upper Carboniferous of Northwest Europe, Blackie, Glasgow, p. 132-152.

Lacchia, A. R., 2016, Ammonoid biostratigraphy of the Shannon Basin, western Ireland. Ph.D. thesis, Trinity College, the University of Dublin, $396 \mathrm{pp}$.

Leeder, M. and McMahon, A., 1988, Upper Carboniferous (Silesian) basin subsidence in northern Britain, in, B.M. Besly and G.K. Kelling, eds., Sedimentation in a Synorogenic Basin Complex: the Upper Carboniferous of Northwest Europe, Blackie, Glasgow, p. 43-52.

Lien, T., R.G. Walker and O.J. Martinsen, 2003, Turbidites in the Upper Carboniferous Ross Formation, western Ireland: reconstruction of a channel and spillover system: Sedimentology, v. 50, p.113-148.

Martinsen, O.J., 1989, Styles of soft-sediment deformation on a Namurian (Carboniferous) delta slope, Western Irish Namurian Basin, Ireland, in, M.K.G. Whateley and K.T. Pickering, eds., Deltas: Sites and Traps for Fossil Fuels, Geological Society of London Special Publication, No. 41, p. 167-177.

Martinsen, O.J. and Collinson, J.D., 2002, The Western Irish Namurian Basin reassessed - a discussion: Basin Research, v. 14, p. 523-542.

Martinsen, O.J., T. Lien, R.G. Walker, 2000, Upper Carboniferous deep water sediments, Western Ireland: Analogues for passive margin turbidite plays: GCSSEPM Foundation Research Conference, Deep-Water Reservoirs of the World, Houston, Texas, p.533-555.

Martinsen, O.J., T. Lien, R.G. Walker and J.D. Collinson, 2003, Facies and sequential organization of a mudstone-dominated slope and basin floor succession: the Gull Island Formation, Shannon Basin, Western Ireland: Marine and Petroleum Geology, v. 20, p. 789-807.

Martinsen, O.J., 2015, Approaches to source-to-sink reconstruction of ancient, outcropping clastic basin-fill successions: examples from the Shannon Basin (Western Ireland) and the 
Western Interior Basin, USA: AAPG Datapages/Search and Discovery Article \#90216, 2015 AAPG Annual Convention and Exhibition, Denver, CO.

McKerrow, W.S. and N.J. Soper, 1989, The lapetus Suture in the British Isles: Geological Magazine, v. 126, p. 1-8.

Pierce, C., P. Haughton, P.M. Shannon, O.J. Martinsen, A.J. Pulham and T. Elliott, 2010, First results from behind-outcrop boreholes in Clare Basin turbidites, Western Ireland: AAPG Annual Convention and Exhibition, 11-14 April, New Orleans, Abstract Volume, \#728613.

Pierce, C. 2016. The Ross Formation revisited. Ph.D. thesis, University College, Dublin (in press). Pulham, A.J., 1989, Controls on internal structure and architecture of sandstone bodies within Upper Carboniferous fluvially-dominated deltas, County Clare, Western Ireland, in, M.K.G. Whateley and K.T. Pickering, eds., Deltas: Sites and Traps for Fossil Fuels: Geological Society of London Special Publication, No. 41, p. 179-203.

Pyles, D.R., 2008, Multiscale stratigraphic analysis of a structurally confined submarine fan: Carboniferous Ross Sandstone, Ireland: American Association of Petroleum Geologists Bulletin, v. 92 , p. 557-587.

Pyles, D.R., L.J. Strachan, L.J. and D.C. Jennette, 2014, Lateral juxtaposition of channel and lobe elements in distributive submarine fans: three-dimensional outcrop study of the Ross Sandstone and geometric model: Geosphere (online), October 15, 2014, doi:

10.1130/GES01042.1.

Rider, M. H., 1974, The Namurian of West County Clare: Proceedings of the Royal Irish Academy, v. 74, p. 125-142.

Rygel, M.C., C.R. Fielding, T.D. Frank, 2008, The magnitude of Late Paleozoic glacioeustatic fluctuations: a synthesis: Journal of Sedimentary Research, v. 78, p. 500-511.

Strachan, L.J., and Allsop, 2006, Slump folds as estimators of paleoslope: a case study from the Fisherstreet Slump of County Clare, Ireland: Basin Research, v. 18, p. 451-470.

Sullivan, M.D., L. Foreman, L, D. Jennette, D. Stern and A. Liesch, 2000, Application of deep water outcrop analog data to 3D reservoir modeling: an example from the Diana Field, Western Gulf of Mexico: AAPG Hedberg Research Conference "Integration of Geological Models for Understanding Risk in the Gulf of Mexico": September 20-24, 1998, Galveston, Texas, USA, 14 pp. 
Sømme, T.O., W. Helland-Hansen, O.J. Martinsen and J.B. Thurmond, 2009, Relationships between morphological and sedimentological parameters in source-to-sink systems: a basis for predicting semi-quantitative characteristics in subsurface systems: Basin Research, v. 21, p. 361-387.

Wignall, P.B. and J.L. Best, 2000, The Western Irish Namurian Basin reassessed: Basin Research, v. 12, p. $59-78$.

Wignall, P.B. and J.L. Best, 2004. Sedimentology and kinematics of a large, retrogressive growthfault system in Upper Carboniferous deltaic sediments, western Ireland: Sedimentology, v. 51, p. 1343-1358. 
FIGURE CAPTIONS
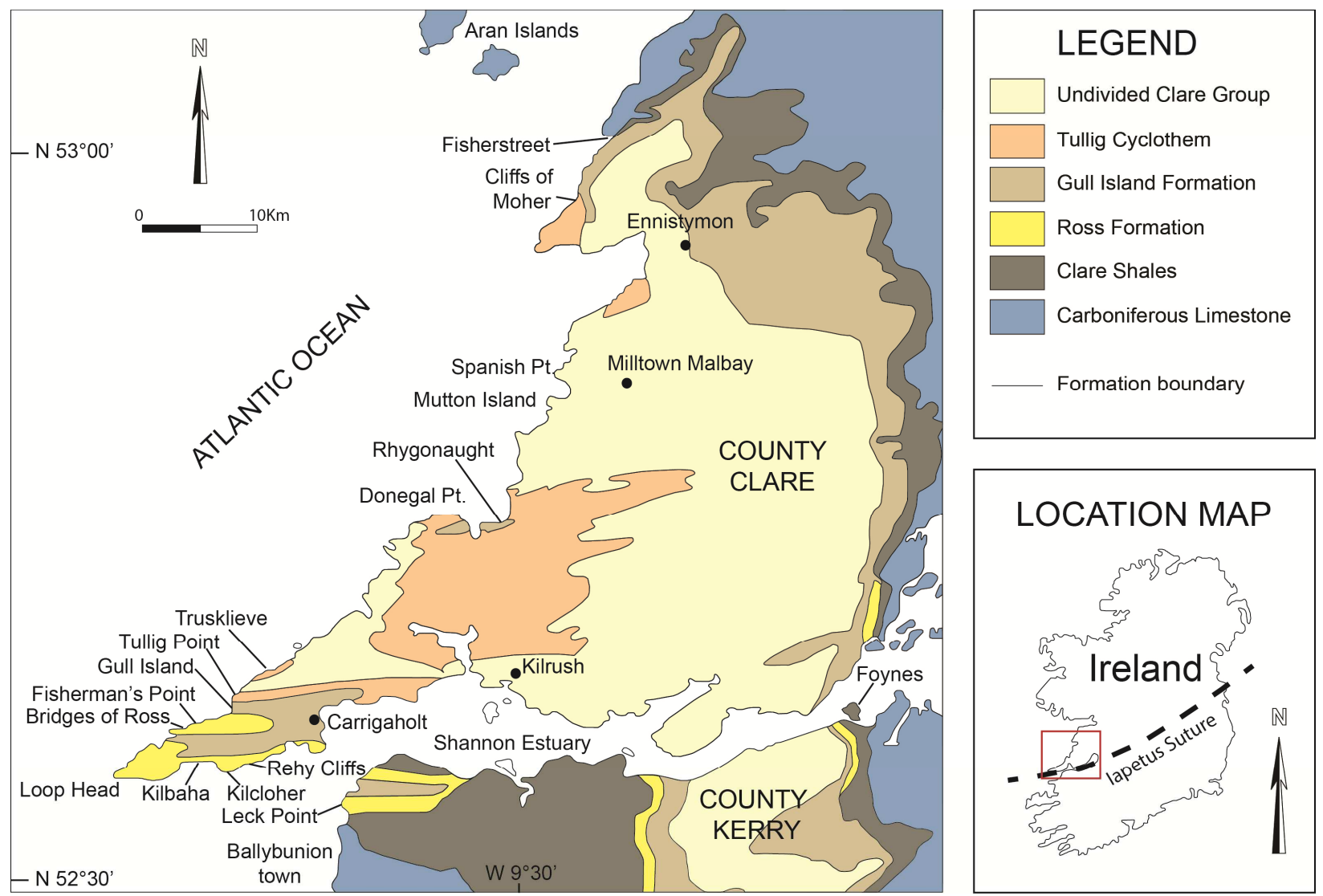

Figure 1: Simplified geological map of the central-northern parts of the Shannon Basin (from Martinsen et al., 2000). 


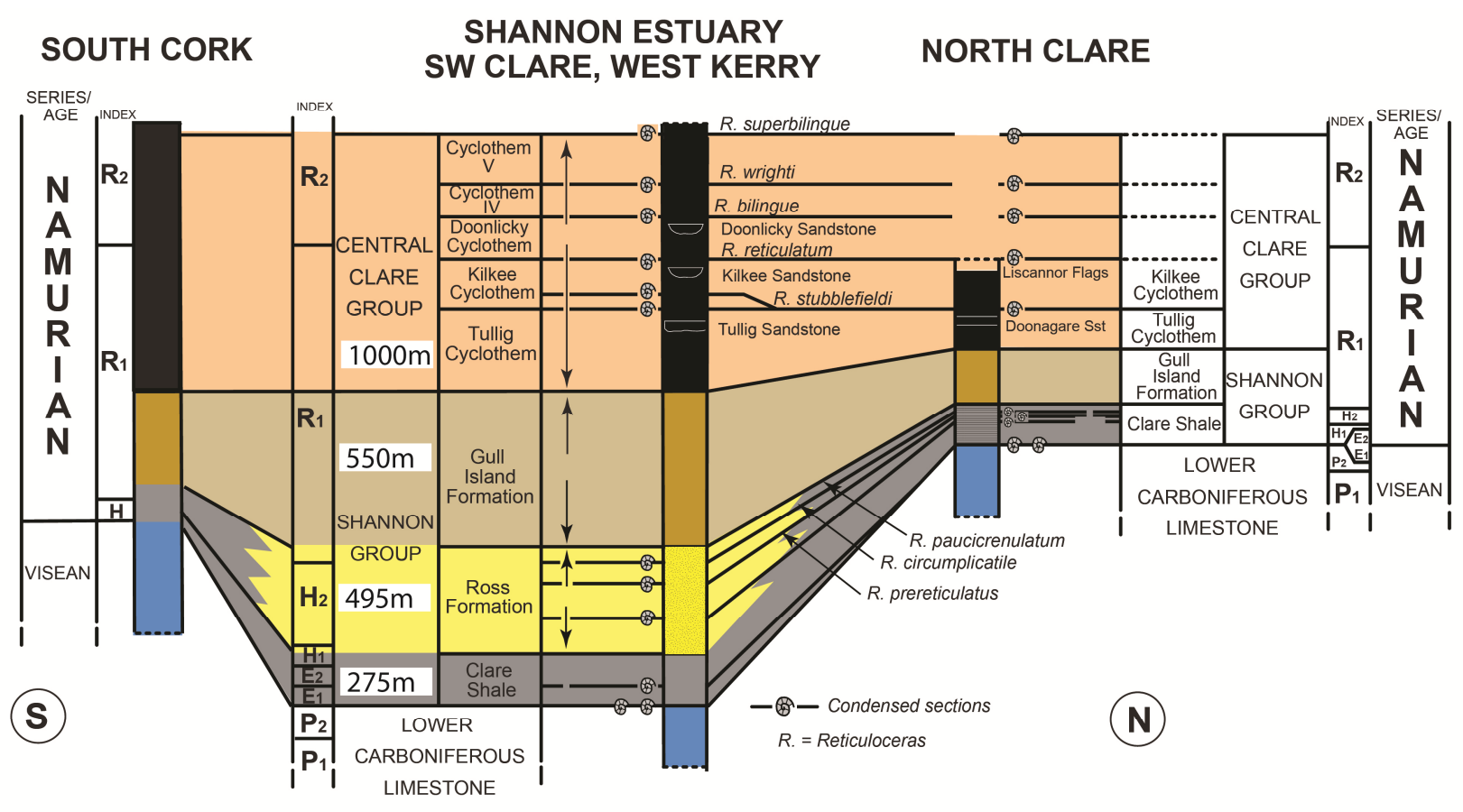

Figure 2: Stratigraphy of the Shannon Basin in a transect from North County Cork through the Shannon Estuary to northern County Clare. Note the vastly thickened basin fill succession in the Shannon Estuary region, considered to be the basin axis set above an extensionally collapsed lapetus Suture. 